\title{
A Confirmatory Analysis of Zakah Compliance Behavioural Intention on Employment Income
}

\author{
ZAINOL BIDIN \\ KAMIL MD IDRIS \\ College of Business \\ Universiti Utara Malaysia
}

\begin{abstract}
A confirmatory test of Ajzen and Fishbein's (1980) theory of reasoned action using structural equation modeling was carried out to study the impact of zakah compliance intention toward employment income. This study had two objectives: 1) to examine the reliability and validity of all variables in the theory of reasoned action using confirmatory factor analysis (CFA), and 2) to determine the relationship between each variable of attitude and subjective norm (obtained from CFA) with zakah compliance intention on employment income. Based on 264 respondents, we used CFA structural equation modeling as the measurement model in measuring attitude, subjective norm, and intention. This study used decomposition of variable in the theory of reasoned action to analyse zakah compliance intention of zakah on employment income. The results of the study indicated that the goodness of fit model comprising attitude, subjective norm, and intention is better when CFA was used. Three components of attitude and two components of subjective norm constructs were found to achieve unidimensionality, and convergent validity and discriminant validity. Thus, this study supported the argument that attitude and subjective norm in the model of zakah on employment income compose of several components and provide good reliability and validity if each component is tested with CFA. Additionally, this study also supported the relationship between attitude and subjective norm with zakah compliance behavioural intention. Recommendations for practice and limitations of the study are also discussed.
\end{abstract}

Keywords: Attitude; subjective norm; intention; zakah; confirmatory factor analysis.

\begin{abstract}
ABSTRAK
Satu ujian pengesahan teori tindakan beralasan yang dibangunkan oleh Ajzen dan Fishbein (1980) dengan menggunakan pemodelan persamaan berstruktur telah dijalankan bagi mengkaji niat gelagat kepatuhan zakat terhadap pendapatan gaji. Kajian ini mempunyai dua objektif: 1) memeriksa kebolehpercayaan dan kesahan semua pemboleh ubah dalam teori tindakan beralasan menggunakan teknik pengesahan analisis faktor, dan 2) menentukan hubungan setiap pemboleh ubah sikap dan norma subjektif (yang diperoleh daripada pengesahan analisis faktor) dengan niat gelagat kepatuhan zakat terhadap pendapatan gaji. Berasaskan 264 responden, kajian ini menggunakan pengesahan analisis faktor sebagai model pengukuran bagi pemboleh ubah sikap, norma subjektif, dan niat. Kajian ini menggunakan kaedah penguraian pemboleh ubah dalam teori tindakan beralasan bagi tujuan analisis niat gelagat kepatuhan zakat terhadap pendapatan gaji. Keputusan kajian menunjukkan bahawa kebagus suaian padanan model yang mengandungi pemboleh ubah sikap, norma subjektif, dan niat adalah lebih baik jika kaedah pengesahan analisis faktor digunakan. Tiga komponen sikap dan dua komponen
\end{abstract}


norma subjektif didapati mencapai tahap unidimensi, kesahan memusat dan kesahan pendiskriminan. Justeru, kajian ini menyokong kenyataan bahawa sikap dan norma subjektif dalam model zakah terhadap pendapatan gaji dapat diuraikan kepada beberapa komponen dan mempunyai keputusan kebolehpercayaan dan kesahan yang baik jika diuji dengan pengesahan analisis faktor. Tambahan pula, kajian ini juga menyokong hubungan antara sikap dan norma subjektif dengan niat gelagat kepatuhan zakat. Cadangan kajian terhadap praktis dan kekangan kajian turut dibincangkan.

Kata kunci: Sikap; norma subjektif; niat; zakat; pengesahan analisis faktor.

\section{INTRODUCTION}

For the past few decades, a number of studies had proposedframeworkstorepresentthedeterminants of behaviour. Some of the frameworks were drawn from social psychological theories such as theory of reasoned action (Ajzen \& Fishbein, 1980; Fishbein \& Ajzen, 1975). Theory of reasoned action has been found very useful in predicting a wide range of behaviours (Hanno \& Violette, 1996; Miniard \& Cohen, 1983; Ryan, 1982) such as on zakah compliance intention behaviour (Zainol \& Kamil, 2007). Although a study carried out by Zainol and Kamil (2007) using the theory of reasoned action in predicting zakah compliance behaviour supported the theory, they did not use the structural equation modeling (SEM) technique. As such, the validity of the variables tested may be questionable because SEM is designed to validate the instruments used to measure the variables under study. It is therefore essential to test for confirmatory factor analysis (CFA) for each variable in the theory in order to prove unidimensionality and establish the reliability and validity of measures (Gerbing \& Anderson, 1988; Hair, Anderson, Tatham, \& Black, 1998).

Structural equation modeling (SEM) is a powerful test of construct validity for scales and is increasingly receiving favourable attention by many researchers (Anderson \& Gerbing, 1988; Fornell \& Larcker, 1981; Hair et al., 1998). One of the advantages of SEM is that latent variables are free of random error. The error has been estimated and removed, leaving only a common variance. Thus, SEM is able to analyse the relationships between latent variables without random error. This allows a more precise test of the relationship among the variables to be conducted. Realising that the study carried out by Zainol and Kamil (2007) did not use rigorous measurement analysis, the present study attempted to fill in the gap by using SEM in establishing the reliability and validity of each variable postulated in the theory of reasoned action. This study hence offers an extension technique using SEM to improve the result of the previous study, especially in establishing unidimensionality. Establishing unidimensionality for each variable is a necessary condition for reliability and validity (Anderson \& Gerbing, 1988). Hence, this study has two objectives: (a) to examine the reliability and validity of all variables in the theory reasoned action on zakah environment, and (b) to determine the relationships between variables of attitude and subjective norm (obtained from CFA) with zakah compliance intention on employment income.

\section{THEORY, PREVIOUS STUDIES, AND HYPHOTESES}

\section{The Theory of Reasoned Action}

The theory of reasoned action (TRA) (Ajzen \& Fishbein, 1980) is a popular theory in explaining and predicting behaviour. It has been shown to predict a wide range of behaviours (Choo, Chung, \& Pysarchik, 2002; Hanno \& Violette, 1996; Miniard \& Cohen, 1983; Ryan, 1982). TRA provides a basis for this study. In this model, behaviour (B) is a direct function of behavioural intention (BI), while behavioural intention is determined by attitude (A) and subjective norms $(\mathrm{SN})$. Intention is the motivational factor that captures how hard people are willing to try to perform a behaviour (Ajzen \& Fishbein, 1980). TRA suggested that behavioural intention is the most influential predictor of behaviour; after all a 
person performs what he intends to do. Attitudes capture a person's feelings of performing the behavior and subjective norms refer to the person's perceptions of others about the specific behaviour. The antecedent of attitude and subjective norms are a set of underlying attitudinal and normative beliefs. Attitudinal belief refers to favourable and unfavourable feelings toward a behaviour, and subjective norms reflect individual perception of the significant referents' judgment about a particular behaviour.

\section{Previous Studies}

Attitude has been defined in many ways (Ajzen \& Fishbein, 1980; Oskamp, 1991; Sherif \& Hovland, 1961). According to Oskamp (1991) attitude refers to things, peoples, places, ideas, actions, or situations. Generally, the literature in psychology has identified that attitude consists of three main elements, i.e. cognitive, affective, and behavioural elements. Thus, attitude toward an object can be investigated by analysing its complex characteristics (Oskamp, 1991). The more complex the attitude toward an object is, the more diverse the opinions are.

Relationship between attitudes and intentions has been well established in the literature (Fishbein \& Ajzen, 1975). This relationship has also been supported by a study conducted by Zainol and Kamil (2007) on zakah compliance intention. Many studies had been conducted on the attitude construct in various fields by using a decomposition approach. These studies identified several factors that contributed to the attitude construct. For instance, Lau (2002) decomposed the attitude construct into five factors. According to his study, the most important variables that correlated with the attitude construct were perceived usefulness, perceived ease of use, perceived benefit, compatibility, and observability. Rhodes and Courneya (2003) decomposed the attitude construct into two factors, i.e affective (enjoyable/ unenjoyable) and instrument (beneficial/harmful). Shimp and Kavas (1984) reported that the attitude construct could be divided into three subsets, i.e. inconvenience, encumbrances, and rewards. In the taxation system, Bobek (1997) identified five scales of attitude measurement, namely tax paid belief, illegal belief, guilt belief, penalty belief, and fairness belief. These five scales were found to significantly influence attitude. Bobek found that the more positive the taxpayer's attitude toward tax payment, the greater the intention to perform the behaviour. Similarly, in the zakah system, Kamil and Mahdzan (2001) decomposed the attitude construct toward zakah on employment income into five dimensions, by using factor analysis. Three out of five dimensions, namely positive acceptability, uncertainty acceptability, and conditional acceptability, were found to significantly influence zakah compliance behaviour. However, Kamil and Mahdzan did not use the theory of reasoned action in which behavioural intention is the main variable. Realising that the theory of reasoned action has been used in a wide range of behaviours, Zainol and Kamil (2007) applied the theory on zakah and employment income. They found that attitude and subjective norm could be decomposed into six and three dimensions, respectively. Three out of six dimensions from the attitude construct were found to be positive and significantly influence compliance behavioural intention toward zakah on employment income. However, Zainol and Kamil did not measure the attitude variable scale thoroughly and this rendered the reliability and validity of the scale used questionable.

The relationship between attitude components toward zakah on employment income and behavioural intention has received substantial empirical support (Zainol \& Kamil, 2007), and thus the following hypotheses were formulated in this study:

$\mathrm{H}_{1}$ Attitude-General Acceptability toward zakah on employement income is positively related with zakah compliance intention on employment income.

$\mathrm{H}_{2}$ Attitude-Conditional Acceptability toward zakah on employement income is positively related with zakah compliance intention on employment income.

$\mathrm{H}_{3}$ Attitude-Positive Acceptability toward zakah on employement income is positively related with zakah compliance intention on employment income. 
Subjective norm is one of the main variables in the theory of reasoned action. The variable is also essential in social learning theory which focuses on the effect of the environment on individuals (Bandura, 1977). Social learning theory stressed that behaviour is a decision made based on the interaction of personal factor and environment. The main factor that determines behaviour comes from peers and other social influences. Various studies found that the subjective norm concept could be decomposed into several relevant reference groups (Chu \& Wu, 2004; Hanno \& Violette, 1996; Oliver \& Bearden, 1985; Shimp \& Kavas, 1984; Zainol \& Kamil, 2007). For example, Chu and Wu (2004) decomposed the reference group into two groups, known as primary normative belief (family and friend) and secondary normative belief (supervisor and peer). Their study showed that the secondary normative belief was found to have positive and significant influence on the intention to behave. In the taxation environment, Hanno and Violette (1996) measured taxpayer's belief by specific reference groups, namely family members, employers, friends, and spouses. In another study, Taylor and Todd (1995) indicated that reference groups such as peers and superiors were found to significantly influence behavioural intention through subjective norm. In zakat, Zainol and Kamil (2007) decomposed the reference groups into three groups, namely intimate reference group, peers reference group, and superior reference group. These three reference groups were found to have significant influence on intention to comply. Again, because their study only used exploratory factor analysis to derive the three groups and not confirmatory factor analysis to examine the reliability and validity of the measures used, the findings revealed might not be as accurate. As such, this study had taken the opportunity to rigorously test the variables and to establish the reliability and validity of subjective norm by using structural equation modeling.

Based on the above discussion, it is important to test the relationship between the subjective norm construct and zakah compliance intention on employment income. Thus, the following hypotheses were developed:
$\mathrm{H}_{4} \quad$ Parent Reference Group of zakah compliance is positively related to zakah compliance intention on employment income.

$\mathrm{H}_{5} \quad$ Peer Reference Group of zakah compliance is positively related to zakah compliance intention on employment income.

$\mathrm{H}_{6}$ Spouse Reference Group of zakah compliance is positively related to zakah compliance intention on employment income.

\section{RESEARCH METHODOLOGY}

\section{Subjects}

In order to determine intention to comply toward zakah on employment income, a survey was conducted in 2005. Data were gathered from Muslim employees of public and private organisations in Kedah. Participants were those who are subjected to scheduled tax deduction scheme (STD). Generally, Muslims who pay income tax are also automatically subjected to zakah payment because the rate deductible for the latter is much less than the former.

To select participants for the present study, a list of large organisations that have at least 20 employees subject to STD was obtained from the state government. Finally 30 organisations that met the criterion were identified. Random sampling technique to select 20 employees in each indentified organisation was used. To do so, a list of employee names was obtained from the organisation. In this manner, the sample size in this study composed of 600 respondents (20 employees in 30 organisations). The sample size used in this study exceeded the requirement suggested by Hair et al. (1998), who recommended that the sample size of between 100 and 200 is appropriate for the purpose of structural equation modeling analysis.

Once 20 employees were selected randomly, they were mailed a questionnaire set with a postage-paid return envelope. A total of 264 usable questionnaires were returned which represent a response rate of $46 \%$. 
A test of non-response bias was conducted by examining the first quarter and last quarter of the respondents. Mean comparisons indicate no significant difference (at $\mathrm{p}<.001$ ) in the study construct between the two groups. It can be concluded that no response bias has occurred in this study.

\section{Data Analysis}

In order to achieve the objective of this study, the data collected were analysed by applying structural equation modeling technique using AMOS 4 (Arbuckle \& Wothke, 1999). Structural equation modeling is a confirmatory technique to data analysis and is currently receiving much attention from researchers (Anderson \& Gerbing, 1988; Fornell \& Larcker, 1981; Hair et al., 1998). Because the theory of reasoned action has been applied and validated in many studies using confirmatory test (Oliver \& Bearden, 1985; Ryan, 1982; Shimp \& Kanvas, 1984), it was justified for the present study to validate the model in the context of zakah compliance environment.

The first phase in the data analysis involved assessing the measurement model using CFA. Multiple goodness of fit indices were used to evaluate the fit of the model against the data. The second phase in the data analysis involved assessing structural model using structural equation modeling. Specifically, in the structural model, relationships between the latent variables of attitude and subjective norms toward zakah compliance intention were tested.

\section{FINDINGS}

\section{Confirmatory Factor Analysis}

Before testing for structural model, the underlying dimensions of attitude and subjective constructs were analysed using CFA. In CFA, the goodness of fit indices were estimated for each latent variable. According to Anderson and Gerbing (1988), CFAis used toestablishunidimensionality, reliability, and construct validity. In the present study, unidimensionality was evaluated by using goodness of fit measures in assessing the model fit for the proposed model. The goodness of fit measures allows for an evaluation of how well the data conform to the proposed structural equation modeling. The fit measures include the normed fit index (NFI), comparative fit index (CFI), Tucker-Lewis index (TLI), and root mean square error of approximation (RMSEA). As recommended by the literature, a model could be considered fit if the NFI, CFI, and TLI are greater than .90 (Arbuckle \& Wothke, 1999; Hair et al., 1998). Further, an RMSEA value above .10 would be unacceptable (Browne \& Cudeck, 1993). The validity of each latent variable consists of convergent and discriminant validity. Convergent validity was determined through assessment of the significance of regression coefficients between indicators and latent factor (Anderson \& Gerbing, 1988) and the average variance extracted (AVE) between the items and the construct (Fornell \& Larcker, 1981), while discriminant validity was assessed through consideration of inter-factor correlations significantly different from 1.0.

In applying CFA via structural equation modeling for each latent variable, we made specifications for the model proposed. The specification model indicated the paths from the latent variable to the measured variables. Factor loadings and error variances were freed for estimation, whereby for the first measured variable was pre-set to 1.0 to create a metric scale or as a reference item. The fit of the proposed model was assessed by examining goodness of fit index, construct reliability, and its loading. If the proposed model did not achieve the standard of goodness of fit, low reliability, and validity, the model should be improved through respecification (purifying). The respecification model involves dropping any measured variable that is not significant or adding other variables in the data set (Hair et al., 1998; Kelloway, 1998).

The measurement model of each of latent variable was examined by performing CFA. The measurement model contained three attitude and three subjective norm latent variables. The results of goodness of fit index, composite reliability, average variance extracted, and factor loading for each latent variable of the attitude and subjective norm construct are shown in Table 
1. Although the chi-square $\left(\chi^{2}\right)$ values for the four latent variables are significant, ${ }^{1}$ all other fit indices are suggestive of a good model fit. Other goodness of fit indices, i.e. NFI, CFI, TLI, for all latent variables were above .90 , indicating no evidence of a lack of unidimensionality. With regard to RMSEA, all latent variables showed acceptable RMSEA values of below .10 except for general acceptability and peer reference group variables that showed RMSEA values of above .10. This suggests a good model fit. Once the unidimensionalty of the variables was established, an assessment of reliability was necessary before looking at construct validity. According to Hair et $a l$. , reliability refers to the degree of a set of latent construct indicators that are consistent in their measurement. One method to assess reliability is through coefficient alpha that has to show a value greater than .70 (Churchill, 1979; Nunnally, 1978). However, through CFA, reliability was measured using composite reliability as suggested by Anderson and Gerbing (1988), and Fornell and Larcker (1981). Typically, a scale is reliable if the value of composite reliability is above .70 (Anderson \& Gerbing, 1988; Fornell \& Larcker 1981; Hair et al., 1998). Fornell and Larcker (1981) argued that an adequate composite reliability indicates sufficient convergent validity of a construct. The composite reliability values for each latent variable, as shown in Table 2, were found to have acceptable reliability. Table 2 also presents the result of composite reliability, average variance extracted, and factor loadings for each latent variable of attitude, subjective norm, and intention. The results indicated that the measurement model of the attitude and subjective norm constructs contained 12 items, respectively. Meanwhile, the intention construct contained only 4 items.

Table 1

Goodness of Fit Index of the Models

\begin{tabular}{lccccccc}
\hline $\begin{array}{l}\text { Latent } \\
\text { Variable }\end{array}$ & $\chi^{2}$ & $\mathrm{P}$ & $\chi^{2 / \mathrm{df}}$ & NFI & CFI & TLI & RMSEA \\
\hline General Acceptability & 8.804 & 0.012 & 4.402 & 0.998 & 0.998 & 0.992 & 0.114 \\
Positive Acceptability & 14.347 & 0.014 & 2.869 & 0.996 & 0.997 & 0.992 & 0.084 \\
Unconditional Acceptability & 4.839 & 0.436 & 0.968 & 0.999 & 1.000 & 1.000 & 0.000 \\
Intimate Referent Group & 0.265 & 0.767 & 0.265 & 1.000 & 1.000 & 1.002 & 0.000 \\
Peers Referent Group & 9.689 & 0.008 & 4.845 & 0.997 & 0.998 & 0.989 & 0.121 \\
Superior Referent Group & 2.724 & 0.066 & 2.724 & 0.998 & 0.999 & 0.995 & 0.081 \\
Compliance Intention & 4.419 & 0.110 & 2.209 & 0.999 & 0.999 & 0.997 & 0.068 \\
\hline
\end{tabular}

Note: $\chi^{2}=$ Chi square; $p=p$ value; $\chi^{2 / d f}=$ chi squarel degree of freedom; NFI= normed fit index; $C F I=$ comparative fit index; $T L I=$ Tucker-Lewis index; $R M S E A=$ root mean square error of approximation

In assessing validity of each variable, we examined convergent validity and discriminant validity of the scales. Convergent validity can be inferred from the standardised factor loadings and composite reliability (Fornell \& Larcker, 1981). The factor loadings for each latent variable of attitude, subjective norm, and intention ranged from .42 to .99 , and all were significant (p $<.01)$. For composite reliability, each latent variable showed an adequate value (above .70) as suggested by Anderson and Gerbing (1988) and Fornell and Larcker (1981). The minimum threshold of .30 of factor loading as suggested by Hair et al. (1998) was achieved. Additional benchmark to assess convergent validity was average variance extracted, in which a value of at least .50 indicates that convergent validity has been achieved (Fornell \& Larcker, 1981). However, according to Hair et al., the average variance extracted, measure is complementary measure to 
the composite reliability. This result demonstrates the measurement's convergent validity for the variables has been achieved (Anderson \& Gerbing, 1988; Fornell \& Larcker, 1981). To assess discriminant validity, we performed correlation between latent variables, which can be inferred from inter-factor correlations significantly different from 1.0. Table 3 indicates that all estimated correlations were found to be significant at $\mathrm{p}<.01$. Hence, this result demonstrated that the discriminant validity of each construct has been achieved.

Table 2

Standardised Confirmatory Factor Loadings

\begin{tabular}{|c|c|c|c|}
\hline $\begin{array}{l}\text { Latent } \\
\text { Variable }\end{array}$ & $\begin{array}{l}\text { Composite } \\
\text { Reliability }\end{array}$ & $\begin{array}{l}\text { Standardised } \\
\text { Loading }\end{array}$ & $\begin{array}{c}\text { Average } \\
\text { Variance Extracted }\end{array}$ \\
\hline General Acceptability & .72 & & .40 \\
\hline Should long be implemented & & .71 & \\
\hline Consent to deduct monthly income & & .67 & \\
\hline Appropriate to impose & & .65 & \\
\hline Failure should be taken action & & .47 & \\
\hline Positive Acceptability & 77 & & .53 \\
\hline Must pay-responsibility in religion & & .82 & \\
\hline Zakah obligatory-condition fulfill & & .70 & \\
\hline Happy to pay & & & .66 \\
\hline Unconditional Acceptability & .74 & & .42 \\
\hline Zakah purify income received & & .74 & \\
\hline Still pay even though unclear & & .66 & \\
\hline If not pay-disobey one of the pillar of Islam & & & .62 \\
\hline If not pay-feel liable to God & & .57 & \\
\hline Parent Referent Group & .96 & & .88 \\
\hline Parent agree & & .86 & \\
\hline Parent support & & .93 & \\
\hline Parent agree & & .98 & \\
\hline Parent think & & .98 & \\
\hline Peers Reference Group & .94 & & .81 \\
\hline Friend agree & & .81 & \\
\hline Friend think & & .98 & \\
\hline Friend support & & .99 & \\
\hline Friend advise & & .80 & \\
\hline Spouse Referent Group & .97 & & .88 \\
\hline Spouse agree & & .98 & \\
\hline Spouse think & & .99 & \\
\hline Spouse support & & .93 & \\
\hline Spouse advise & & .84 & \\
\hline Compliance Intention & .87 & & .65 \\
\hline To contact zakah institution & & .42 & \\
\hline To add zakah payment & & .84 & \\
\hline I will pay zakah every year & & .89 & \\
\hline I will pay zakah & & .97 & \\
\hline
\end{tabular}

Note: All loadings reported are standardised. Construct reliability $=$ (sum of standardised loading) ${ }^{2} /\{$ (sum of standardised loadings) ${ }^{2}+$ sum of indicators measurement error $\}$. Indicator measurement error $=1$ - (standardised loading $)^{2}$. Average variance extracted $=$ sum of squared standardised loading $/$ (sum of squared standardised loadings + sum of indicator measurement error). All factors loading are significant at $\mathrm{p}<0.01$. 
Table 3

AMOS Estimates of Correlations among Latent Variables

\begin{tabular}{lcccccc}
\hline Latent variables & 1 & 2 & 3 & 4 & 5 & 6 \\
\hline 1. General Acceptability & - & & & & & \\
2. Positive Acceptability & .58 & - & & & \\
3. Unconditional Acceptability & .75 & .63 & - & & \\
4. Parent Reference Group & .50 & .35 & .47 & - & \\
5. Peers Reference Group & .45 & .24 & .35 & .64 & - & \\
6. Spouse Reference Group & .36 & .13 & .27 & .52 & .62 & - \\
\hline
\end{tabular}

Note: All estimate correlations are significant at $\mathrm{p}<.01$

\section{Structural Model}

The structural model analysis involved evaluation $=.41$, respectively, while positive acceptability of relationships between the latent variables. In $\left(H_{2}\right)$ was significant at $\mathrm{p}<.05, \beta=.13$. For the Table 4, the attitude and subjective norm variables were found to be related to compliance intention. The strength of the relationships between the constructs was represented by standardised path coefficients. Inspection of coefficients of the structural model indicated that among six independent variables, five were significantly related to zakah compliance intention. General acceptability $\left(H_{1}\right)$ and unconditional acceptability $\left(\mathrm{H}_{3}\right)$ were found to have significant effects on compliance intention at $\mathrm{p}<.01, \beta=.30$ and $\beta$ subjective norm, the parent reference group $\left(H_{4}\right)$ and the spouse reference group $\left(H_{5}\right)$ were found to significantly influence compliance intention at $\mathrm{p}<.01, \beta=.25$ and $\beta=.30$, respectively. Meanwhile, peer reference group $\left(H_{6}\right)$ did not have any significant influence $(\mathrm{p}>.05)$. As indicated in Table 4, large significant effects were shown by unconditional acceptability. The total explained variance (squared multiple correlation) of these variables on zakah compliance intention was $44 \%$.

\section{Table 4}

\section{Standardised Path Coefficients for Structural Model}

\begin{tabular}{lcc}
\hline Paths/Hypothesizes & Coefficient & Verification results \\
\hline General Acceptability - Zakah Compliance intention & $.30^{*}$ & Supported \\
Positive Acceptability - Zakah Compliance intention & $.13^{* *}$ & Supported \\
Unconditional Acceptability - Zakah Compliance intention & $.41^{*}$ & Supported \\
Parent Reference Group - Zakah Compliance intention & $.25^{*}$ & Supported \\
Peers Reference Group - Zakah Compliance intention & .10 & Not Supported \\
Spouse Reference Group - Zakah Compliance intention & $.30^{*}$ & Supported
\end{tabular}

$* \mathrm{p}<.01 . * * \mathrm{p}<.05$ 


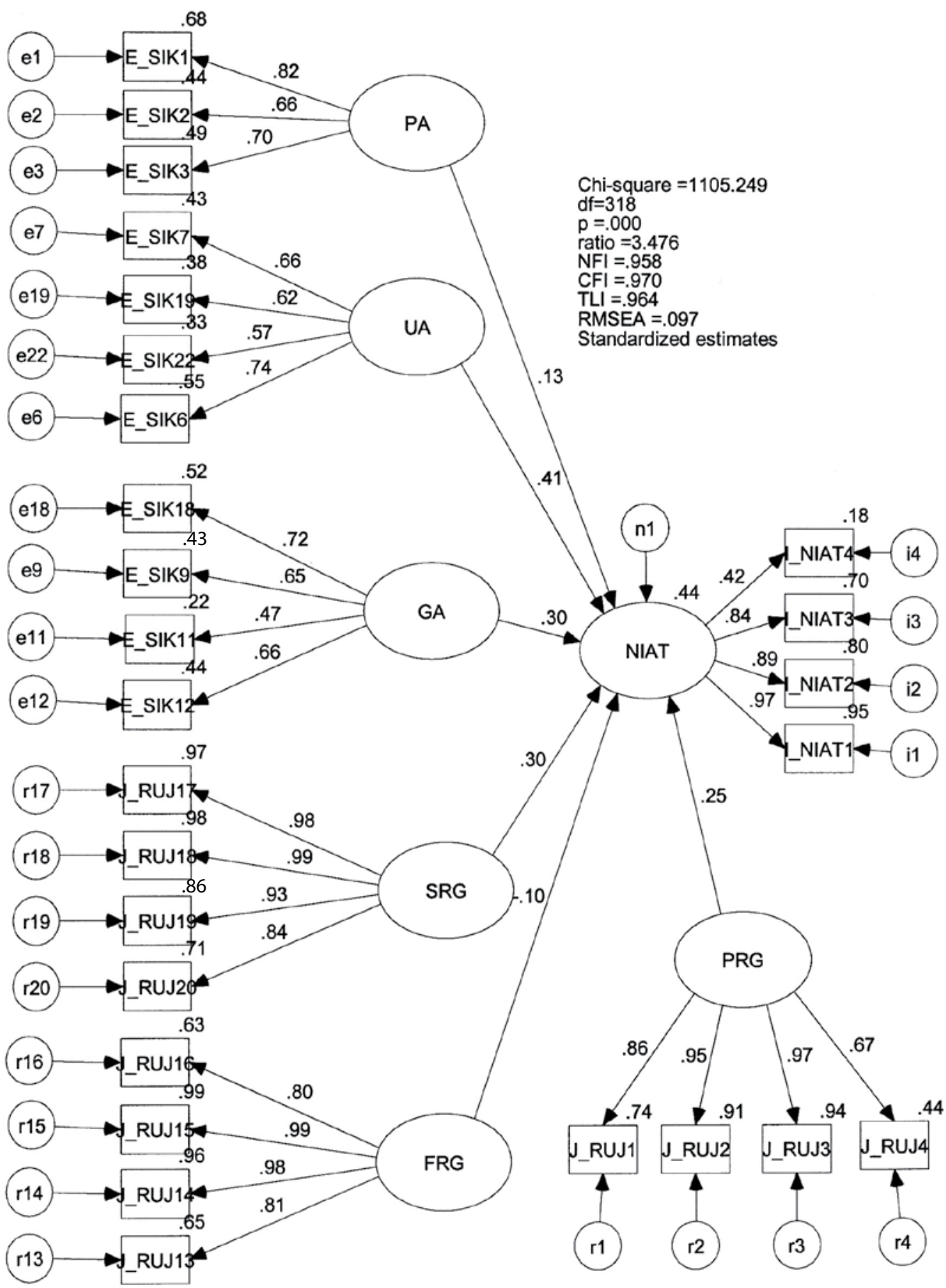

Figure 1

Structural model of zakah compliance intention

Note: INT= intention; $\mathrm{PA}=$ Positive Acceptability; $\mathrm{UA}=$ Unconditional Acceptability; GA= General Acceptability; PRG = Parent Referent Group; FRG= Peer Referent Group; SRG= Spouse Referent Group 
The result of the SEM test for the fit statistics of the model provides a good fit to the data $\left(\chi^{2}=1105.249, \mathrm{p}<.01 ;\right.$ Chi-square/degrees of freedom $\left(\chi^{2} / \mathrm{df}\right)=3.476 ; \mathrm{NFI}=.958 ; \mathrm{CFI}=.970$; TLI $=.964 ;$ RMSEA $=.097)$. Although the chisquare value was significant, all other fit indices showed a good model fit. Figure 1 indicates that all path coefficients were significant, except for the path from peer reference group to intention. The ability of this model to explain behavioural intention was good with squared multiple correlation (SMC) of .44.

\section{DISCUSSION}

The results of this study have several implications for the application of reasoned action theory on zakah compliance. The first objective of this study was to examine the validity and reliability of the attitude and subjective norm for Muslim employees toward zakah on employment income through structural equation modeling. The result from CFA indicated that attitudes and subjective norms toward zakah on employment income among Muslim employees were multidimensional. This suggested that the atttitude construct is complex and confirms the latitude theory (Sherif \& Hovland, 1961), which argued that attitudes are complex and can be decomposed into several components (Chu \& Wu, 2004; Lau, 2002; Taylor \& Todd, 1995). This claim is strongly supported when the use of CFA for each component of the attitude achieved reliability, and convergent and discriminant validity in the present study. The underlying factors of the attitude construct are general acceptability, positive acceptability, and unconditional acceptability. Subsequent findings using structural equation modeling indicated that these three factors have significant influence on zakah compliance intention.

The three factors identified above in the present study indeed has important practical implications. Zakah institutions need to understand that firstly, intention to pay zakah on employment income is indeed an important aspect that needs to be understood since intention to comply with zakah is influenced by attitudes toward that behaviour. The present study has shown that zakah institutions need to consider developing the three components of attitude as a prerequisite for zakah compliance intention through various concerted programmes and strategies. The findings of the present study are parallel with those of previous studies that found the three factors to have significant effects on zakah compliance intention (Zainol \& Kamil, 2007) and zakah compliance (Kamil \& Mahdzan, 2001).

Another key finding of the present study is that the decomposition of subjective norm resulted into two components i.e. parent reference group and spouse reference group being significantly related to zakah compliance intention; the other component peer reference group was not related to intention. By using CFA for construct validation, each component of the subjective norm achieved reliability, and convergent and discriminant validity. Thus, this finding suggests that although subjective norm influenced zakah compliance intention, the parent and spouse reference groups were important determinants of zakah compliance intention. This shows that Muslims will comply with zakah payment when people close to them, such as their spouse and parents think that such religious obligation is important. Furthermore, this study warns that when using rigourous measurement analysis (using CFA) for each latent variable of subjective norm construct, the findings indicate that two of three components influenced significantly on zakah compliance intention. Furthermore, this finding is consistent with previous studies, which identified that spouse or parents, had significant influence on behavioural intention (Oliver \& Bearden, 1985; Zainol \& Kamil, 2007).

The findings of this study also confirm that the reliability and validity of the theory of reasoned action were good when applied to the domain of zakah compliance intention. Hence, this offers a much more solid theoretical basis for the study of compliance behaviour and can be used as guide for future research design.

Although this study found that attitude and subjective norm are essential variables in predicting zakah compliance intention, different results may be obtained when theory of planned behaviour, an extension of theory of reasoned 
action, by inclusion an additional construct known as perceived behavioural control (Ajzen, 1991), is used. Perceived behavioural control is appropriate to apply when an individual faces incomplete control in performing a particular behaviour.

\section{CONCLUSION}

Our findings support Ajzen and Fishbein's (1980) conclusion that attitude and subjective norms significantly predict behavioural intention. This study has presented the instrument for measuring attitude, subjective norm, and intention model on Muslim employees toward zakah compliance intention. The findings of the study have demonstrated that attitude and subejective norm toward zakah on employment income can be decomposed into smaller components. The study has shown that the components have achieved unidimensionality, reliability, and convergent and discriminat validity through the process of CFA. In addition, general acceptability, positive acceptability, unconditional acceptability, parent reference group, and spouse reference group were found to significantly relate to zakah compliance intention. Thus, it provides useful information to zakah authorities to improve their zakah collection among Muslim employees by focusing on the specific component of attitude and subjective norm.

While the findings of the present study have been able to furnish us with useful understanding about what influences intention to pay zakah on employment income amongst Muslim employees, they are limited to the context of Kedah only and hence may have limited generalisability. To what extent such findings reflect a much larger population residing in other states in Malaysia is yet to be ascertained since religious matters are within state and not federal jurisdiction. In this case, it will be very interesting to find out whether differences and/or similarities in the phenomenon under study can be ascertained. Furthermore, the present study assumed that attitude toward zakah behaviour is given. Realistically and theoretically speaking, attitudes are formed due to multitude of factors, such as the context one is in. In this regard, comparative studies across different states may reveal something important and useful for practice and theory.

\section{END NOTE}

${ }^{1}$ The $\chi^{2}$ has been recognised as an inappropriate test for large sample size (Hair et al., 1998).

\section{REFERENCES}

Ajzen, I. (1991). The theory of planned behaviour, Organisational Behaviour and Human Decision Processes, 50, 179-211.

Ajzen, I., \& Fishbein, M. (1980). Understanding attitudes and predicting social behaviour, Englewood Cliffs, NJ: Prentice-Hall.

Arbuckle, J. L., \& Wothke, W. (1999). AMOS users' guide version 4.0. Chicago IL: Smallwaters Corporation.

Anderson, J., \& Gerbing, D. (1988). Structural equation modeling in practice: A review and recommended two-step approach, Psychological Bulletin, 103, 3, 411-423.

Bandura, A. (1977). Social learning theory. Englewood Cliffs: Prentice Hall.

Bobek, D. D. (1997). Tax fairness: How do individuals Judges Fairness And What Effects Does It Have On Their Behaviour. Ph.D. Dissertation, University of Florida, Gainesville.

Browne, M.W., \& Cudeck, R. (1993). Alternative ways of assessing Model Fit, in . K.A. Bollen \& J.S. Long (Eds.). Testing Structural Equation Models. Newbury Park, CA: Sage, 136-62.

Choo, H., Chung, J.E., \& Pysarchik, D.T. (2002). Antecedents to new product purchasing behavior among innovator groups in India, European Journal of Marketing, 38 (5/6), 608-625. 
Chu, P.Y., \& Wu, T.Z. (2004). Factors influencing tax-payer information usage behavior: Test of an Integrated Model, The Eighth PacificAsia Conference on Information Systems, Shanghai, China.

Churchill, G.A., Jr. (1979). A paradigm for developing better measures of marketing constructs. Journal of Marketing Research, 16 (1), 64-73.

Fishbein, M., \& Ajzen, I. (1975). Belief, attitude, intention, and behaviour: An introduction to theory and research, Reading, MA: Addison-Wesley.

Fornell, C., \& Larcker, D. (1981). Evaluating structural equation models with unobserved variable and measurement error. Journal of Marketing Research, 18, 39-50.

Gerbing, D.W., \& Anderson, J.C. (1988). An updated paradigm for scale development incorporating unidimensionality and its assessment, Journal of Marketing Research, 25 (2), 186-92.

Hanno, D., \& Violette, G.R. (1996). An analysis of moral and social influences on taxpayer behaviour. Behavioural Research in Accounting, 8, 57-75.

Hair, J.F., Anderson, R.E., Tatham, R.L., \& Black, W.C. (1998). Multivariate data analysis. New Jersey: Prentice Hall.

Kamil, \& Ahmad Mahdzan (2001). Attitude towards zakah on employment income: comparing outcomes between single score and multidimensional scores, Malaysian Management Journal, 5 (1\&2), 47-63.

Kelloway, E.K. (1998). Using LISREL for Structural Equation Modeling. Thousand Oaks: SAGE Publications.

Lau, A.S.M. (2002). Strategies to motivate brokers adopting on-line trading in Hong Kong financial market, Review of Pacific Basin Financial Markets and Policies, 5(4), 471-489.
Miniard, P.W., \& Cohen, J.B. (1983). Modeling personal and normative influences on behaviour. Journal of Consumer Research, 10, 169-180.

Nunnally, J.C. (1978). Psychometric theory (2nd ed.). New York: McGraw-Hill.

Oliver, R.L., \& Bearden, W.O. (1985). Crossover effects in the theory of reasoned action: A moderating influence attempt. Journal of Consumer Research, 12, 324-340.

Oskamp, S. (1991). Attitude and opinions (2nd ed.). Englewood Cliffs: Prentice Hall.

Rhodes, R.E., \& Courneya, K.S. (2003). Investigating multiples components of attitude, subjective norm, and perceived control: An examination of the theory of planned behavior in the exercise domain. British Journal of Social Psychology, 42, 129-146.

Ryan, M.J. (1982). Behavioural Intention formation: The interdependency of attitudinal and social influence variables. Journal of Consumer Research, 9, 263278.

Sherif, M., \& Hovland, C.I. (1961). Social judgement: Assimilation and contrast effects in communication and attitude change. New Haven: Yale Universiti Press.

Shimp, T.A., \& Kavas, A. (1984). The theory of reasoned action applied to coupon usage. Journal of Consumer Research, 11, 795809.

Taylor, S., \& Todd, P. (1995). Decomposition and crossover effects in the theory of planned behavior: A study of consumer adoption intentions, International Journal of Research in Marketing, 12, 137-55.

Zainol \& Kamil. (2007). The role of attitude and subjective norm on intention to comply zakah on employment income. IKaZ International Journal of Zakah, 1,1 . 